\title{
Article
}

\section{Positioning Food Safety in Halal Assurance}

Demirci, M, N, Soon, Jan Mei and Wallace, Carol Anne

Available at http://clok.uclan.ac.uk/15339/

Demirci, M, N, Soon, Jan Mei ORCID: 0000-0003-0488-1434 and Wallace, Carol Anne ORCID: 0000-0002-1402-2134 (2016) Positioning Food Safety in Halal Assurance. Food Control, 70 . pp. 257-270. ISSN 0956-7135

It is advisable to refer to the publisher's version if you intend to cite from the work. http://dx.doi.org/10.1016/j.foodcont.2016.05.059

For more information about UCLan's research in this area go to http://www.uclan.ac.uk/researchgroups/ and search for < name of research Group>.

For information about Research generally at UCLan please go to http://www.uclan.ac.uk/research/

All outputs in CLoK are protected by Intellectual Property Rights law, including Copyright law. Copyright, IPR and Moral Rights for the works on this site are retained by the individual authors and/or other copyright owners. Terms and conditions for use of this material are defined in the policies page.

\section{CLoK}

Central Lancashire online Knowledge www.clok.uclan.ac.uk

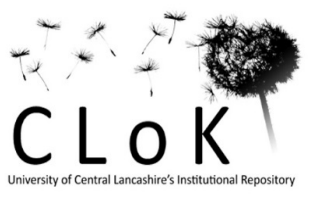


1 Positioning Food Safety in Halal Assurance

2 Marin Neio Demirci ${ }^{1}$, Jan Mei Soon and Carol A. Wallace

3 International Institute of Nutritional Sciences and Applied Food Safety Studies, School of Sport and Wellbeing, 4 University of Central Lancashire, Preston, Lancashire PR1 2HE, United Kingdom

\section{ABSTRACT}

6 Muslims follow the religion of Islam and the food they eat should be Halal, meaning lawful or permissible.

7 Muslims are allowed to eat halal and wholesome food that has been provided for them. However, some of the 8 main prohibitions are swine flesh, blood, carrion, animals not slaughtered according to Islamic laws and 9 alcoholic drinks. At present Halal assurance is in a complicated state, with various Halal standards differing influential globally accepted standard that would open doors to global markets and gain consumer confidence. This paper discusses issues mainly related to food safety in Halal assurance. The aim was to discover and describe the approach to food safety requirements in Halal food provision and how this is incorporated in the Halal assurance systems. The position of food safety regulation within Halal requirements or Halal standards' requirements for food safety is still unclear. This review also considers whether current Halal standards include criteria in common with internationally accepted food hygiene standards and emphasizes the potential of using the HACCP system for Halal assurance.

\section{Keywords: Certification, GHP, GMP, Halal standard, Halalan and Toyyiban, HACCP, Haram, Islam, Sharia}

\section{Introduction}

International trade, migration and travel are increasing and as a result contaminated food might find its way into many countries and be a threat to a wide range of consumers (WHO, 2007). Product recalls due to contaminated ingredients will considerably damage producers' and might even damage countries' reputation affecting trade, tourism and international relations (WHO, 2007). Food safety standards and certification are crucial to ensure food safety and are important for trade and consumer trust (ISO, 2015). One important food certification is Halal assurance. Halal is an Arabic phrase referring to lawful and permissible according to Islamic law and principles. Halal foods are foods that are free from any components that Muslims are prohibited from consuming (Riaz \& Chaundry, 2004). Just like contaminated food, food believed to be Halal, but actually not so, can spread and find its way to Muslims around the globe, which is a reason why Halal standards and certification are crucial in Halal assurance. The more complicated question, which will also be addressed in this study, lies in the food safety expectations of Halal food and how the concept of Halal is interpreted regarding food safety. In other words, are the food production methods believed to produce Halal products also following necessary food safety requirements and should they do so?

No matter the geographical position or ethnic diversity, the religion of Islam is a way of life for Muslims and eating Halal is an inseparable part of a Muslim's life (Riaz \& Chaundry, 2004). The global Muslim population in 2010 was approximately 1.6 billion, which makes $23.4 \%$ of the world's population. It is estimated to continue increasing. There are around 49 Muslim-majority countries, which are situated mainly in the Middle East, South-East Asia regions and Africa, where around 74\% of the global Muslim population are situated. However, around 26\% of the global Muslim population live in Muslim-minority countries (Pew Research Center, 2011). The Muslim population is spread across the seven continents and it is acknowledged that the Halal market has great potential for both Muslim and non-Muslim countries for local producers and exporters alike (WHF, 2009; International Trade Centre, 2015). The Halal food market's potential is constantly rising with the global market value of about USD547 billion in 2006, USD720 billion in 2009 (H-Media, 2011) and an estimated USD1.37 trillion in 2014 (International Trade Centre, 2015). To be a part of that market it can be a benefit, especially for non-Muslim countries, to have Halal certification and labelling (Ruzevicius, 2012; International Trade Centre, 2015). Although, a trustable Halal certification scheme may support export, it is equally important for Muslimmajority countries to develop their Halal food industry to protect their consumers from consuming non-Halal products (Ratanamaneichat \& Rakkarn, 2013).

The main aim of Halal certification is to determine whether a product to be consumed by Muslims is Halal or not. After obtaining the certification, companies could use Halal labels on their packages, which is necessary for consumers to make informed decisions (Shariff \& Abd Lah, 2014). Muslims are supposed to make an effort to obtain Halal food of good quality and refrain from things that are doubtful to be sure to avoid consumption of haram (prohibited and unlawful) substances (Riaz \& Chaundry, 2004). Hence, a Halal logo on the package

\footnotetext{
${ }^{1}$ Corresponding author.

E-mail address: mrn.neio@gmail.com (M. Neio Demirci)
} 
could give the necessary assurance and eliminate consumers' uncertainty (Batu \& Regenstein, 2014). However, various Halal logos are used, which in turn reflect different Halal standards (Halim \& Salleh, 2012). Therefore, it is important, that Halal certification bodies (CB) would have competence in awarding certification, which accurately reflects correct and expected Halal practices by the producer(Din \& Duad, 2014).

In the late 1980s, in order to penetrate the South-East Asia and Middle East markets, the certification and production of Halal foods started to increase (Riaz \& Chaundry, 2004). The Halal certification process started from meat and poultry products and with the initiative of the South East Asia countries expanded to processed foods (H-Media, 2011). Since a public body did not exist to guide the process, the interpretation of Halal assurance and responsibility for Halal certification were dependent on various institutions like local mosques, governmental, part-governmental bodies and private organisations (IHIA, 2015). Moreover, at present a halal certificate is allowed to be issued by any Muslim, Islamic company or association, however, the key is the acceptability of the certificate by the interested party (Hanzaee \& Ramezani, 2011). From an estimated 300 Halal certification bodies around the world, only around a 120 are officially registered as active Halal certification bodies (CBs) (IHIA, 2015). It is also worth to note, that despite the large number of certification agencies, Arabic countries, representative of the largest Muslim consumer market, do not play a significant role in Halal standards and harmonizing certification (Hashimi, et al., 2010).

In the global Halal industry a fast growing sector is logistics (H-Media, 2011). This is also demonstrated by studies on the Halal supply chain (Zailani, et al., 2010; Omar, et al., 2013; Muhammad, et al., 2009; Talib, et al., 2015; Manzouri, et al., 2013; Tieman, et al., 2012; Tieman, 2011; Ngah, et al., 2014; Zulfakar, et al., 2014), logistics (Tarmizi, et al., 2014; Tan, et al., 2012; Iberahim, et al., 2012; Tieman, 2013; Tarzimi, et al., 2014; Talib \& Hamid, 2014; Tieman, et al., 2013; Kamaruddin, et al., 2012; Tieman \& Ghazali, 2014) and traceability (Poniman, et al., 2015; Zailani, et al., 2010; Samsi, et al., 2012; Shafii \& Khadijah, 2012). The logistics sector is trying to take a step further by suggesting a minimum standard for non-Muslim countries and a preferred standard for Muslim countries, which non-Muslim countries could adopt over time (Tieman, 2013). However, these efforts might be of little consequence if approaches like conventional Halal certification still exist, which covers only the slaughtering process (Bonne \& Verbeke, 2008; Tieman, 2013), e.g. in Belgium, it is only certified whether the slaughterer is a Muslim (Bonne \& Verbeke, 2008). However, another extreme is well demonstrated by Malaysia with its governmental support for Halal assurance and with the publication of multiple Halal standards covering different sectors (HDC, 2015; Department of Standards of Malaysia, 2009). Moreover, a majority of research on the Halal food industry (Abdul, et al., 2009; Abdullah, et al., 2007; Afifi, et al., 2013; Noordin, et al., 2009; Marzuki, et al., 2012; Mohamed \& Backhouse, 2014; Latif, et al., 2014; Badruldin, et al., 2011; Shariff \& Abd Lah, 2014) (Shallah \& Hussin, 2013; Samori \& Sabtu, 2014; Talib, et al., 2010; Majid, et al., 2015; Yunus, et al., 2010; Kadir, et al., 2015; Bohari, et al., 2013; Tahir \& Abdul, 2013; Omar, et al., 2014; Rahman, et al., 2013) and consumer awareness of Halal food (Abdul, et al., 2009; Ahmad, et al., 2013; Ambali \& Bakar, 2014; Golnaz, et al., 2012; Golnaz, et al., 2010) is conducted in Malaysia.

Possibly due to variations in Halal requirements' interpretation and different standards used for Halal certification, at present divergence within Halal assurance activities is prevailing (Pointing, 2014). This paper aims to find out how the concept of Halal is interpreted regarding food safety requirements and whether they are incorporated into Halal assurance systems.

\section{Materials and Methods}

Literature searches were conducted on the topics of Halal requirements, standards, certification and legislation to get an overview of the latest developments on Halal assurance systems. In addition, research was conducted on topics like food safety management systems in Muslim-majority countries and using the HACCP systemfor Halal assurance.

First, an overview was made on the basic Halal requirements showing how food safety would be a part of the Halal concept. Furthermore, Halal standards, Halal certification and food safety assurance were discussed. In addition, an analysis was made on how basic food safety practices are integrated into one Halal standard and whether they are sufficient to assure food safety. Finally, the broadening of the Hazard Analysis and Critical Control Point (HACCP) system as a Halal assurance tool was analysed and discussed.

The literature research was conducted by using various databases like ScienceDirect, Springer Link, EBSCO, IEEE Xplore, Taylor and Francis Online, ACG publications, Scientific Journals. Conference proceedings, reports, books, guidelines, Codex Alimentarius Commission standards, online newspapers, open-access articles, governmental, various organisations' websites and legislation were included in the study. The latest peer-review articles on the topic were mainly used. Since Halal assurance is a fairly new area of research, conference papers were used to fill information gaps and include latest research. The Codex Alimentarius Commission (CAC) General Principles of Food Hygiene (CAC/RCP 1-1969) state the main requirements for hygienic and safe food 
109 production. These requirements were used as the base guidelines to compare with the Malaysian Standard 110 MS1500:2009 Halal Food - Production, Preparation, Handling and Storage (MS 1500:2009) requirements for 111 hygienic and safe food production practices.

\section{$112 \quad 3$. Results and discussion}

\section{3.1 Halal and Toyyiban}

114 At the beginning of Islam there were no government food safety regulations and Islamic dietary laws were the only regulations for safe and wholesome food products (Riaz \& Chaundry, 2004). In their lives Muslims follow what is Halal, which guides their way of life and an aspect of that is the food they eat. The most important sources of Islamic law or Shariah and hence determining what is Halal and Haram are the Quran and the Sunnah and Hadith (the actions and teachings of Prophet Muhammad), followed by ijtihad (legal reasoning) and fatwa (legal verdict) of qualified scholars of the Muslim community, which are important with regards to finding answers to contemporary issues (Kamali, 2008). When necessary Halal certification bodies could seek guidance from Muslim legal experts (muftis) and expert bodies, like the International Islamic Fiqh Academy, the Department of Islamic Development Malaysia (JAKIM), the Indonesian Council of Ulama (MUI) etc. (OIC, 2016; JAKIM, 2016; LPPOM MUI, 2016).

The main requirements include the prohibition of swine flesh, blood, carrion, animals not slaughtered according to Islamic laws and alcoholic drinks, which could be found in the Qur'an 2:173, 2:219, 5:90, 5:3, 6:118, 6:119, 6:121, 6:145 and 16:115. In addition, the Quran contains various nutritional concepts (Tarighat-Esfanjani \& Namazi, 2014). To distinguish the degree of validity of the Hadith, they were classified according to their authenticity using rigid criteria. Although not the only one and not complete, a widely accepted and considered as one of the most authentic collections is by al-Bukhari (Akgündüz, 2010). Some of the Hadith regarding food include:

Narrated Al-Bara’ and Ibn Abi 'Aufa: The Prophet prohibited the eating of donkey’s meat. (Sahih al-Bukhari, Vol. 7, Book 67, Hadith 434);

Narrated Abu Tha'laba: Allah's Messanger forbade the eating of the meat of beasts having fangs (Sahih alBukhari, Vol. 7, Book 67, Hadith 438);

Narrated Rafi'bin Khadija: The Prophet said, “Eat what is slaughtered (with any instrument) that makes blood flow out, except what is slaughtered with a tooth or a nail.” (Sahih al-Bukhari, Vol. 7, Book 67, Hadith 414);

In addition, in the Qur'an verses regarding eating and food containing phrases “Halalan Toyyiban” (Qur'an, 2:168, 5:88, 8:69 and 16:114) and “Toyyiban” (Qur'an, 2:172, 5:4, 5:5, 7:160 and 20:81) are brought out in Table 1. Toyyiban is an Arabic word that could be translated as "good or wholesome" (Hashimi, et al., 2010). Arif and Ahmad (2011) refer to a more detailed translation as in good, agreeable, palatable, pleasant, pleasing, delightful, delicious, sweet, embalmed, perfumed and soothing to one's mind. They also bring out a term "Altayyibat”, which describes the moral virtues and obligations associated with the products and refers to goods that are halal and pure (Arif \& Ahmad, 2011).

144 Table 1. The phrases from the Qur'an regarding Toyyiban:

\begin{tabular}{|c|c|}
\hline $\begin{array}{l}\text { The Chapter and Verse in the } \\
\text { Qur'an }\end{array}$ & Phrases from the Qur'an \\
\hline Chapter 2, Verse 168 & $\begin{array}{l}\text { "O mankind, eat from whatever is on earth [that is] lawful and good and do not follow the } \\
\text { footsteps of Satan. Indeed, he is to you a clear enemy." }\end{array}$ \\
\hline Chapter 5, Verse 88 & $\begin{array}{l}\text { "And eat of what Allah has provided for you [which is] lawful and good. And fear Allah, in } \\
\text { whom you are believers." }\end{array}$ \\
\hline Chapter 16, Verse 114 & $\begin{array}{l}\text { "Then eat of what Allah has provided for you [which is] lawful and good. And be grateful for } \\
\text { the favour of Allah, if it is [indeed] Him that you worship." }\end{array}$ \\
\hline Chapter 2, Verse 172 & $\begin{array}{l}\text { "O you who have believed, eat from the good things which We have provided for you and be } \\
\text { grateful to Allah if it is [indeed] Him that you worship." }\end{array}$ \\
\hline Chapter 5, Verse 4 & $\begin{array}{l}\text { "They ask you, [O Muhammad], what has been made lawful for them. Say, "Lawful for you are } \\
\text { [all] good foods and [game caught by] what you have trained of hunting animals which you } \\
\text { train as Allah has taught you. So eat of what they catch for you, and mention the name of Allah } \\
\text { upon it, and fear Allah." Indeed, Allah is swift in account." }\end{array}$ \\
\hline Chapter 5 , Verse 5 & $\begin{array}{l}\text { "This day [all] good foods have been made lawful, and the food of those who were given the } \\
\text { Scripture is lawful for you and your food is lawful for them...." }\end{array}$ \\
\hline Chapter 7, Verse 160 & $\begin{array}{l}\text { "And We divided them into twelve descendant tribes [as distinct] nations. And We inspired to } \\
\text { Moses when his people implored him for water, "Strike with your staff the stone," and there } \\
\text { gushed forth from it twelve springs. Every people knew its watering place. And We shaded }\end{array}$ \\
\hline
\end{tabular}


them with clouds and sent down upon them manna and quails, [saying], "Eat from the good things with which We have provided you. "And they wronged Us not, but they were [only] wronging themselves"

Chapter 8, Verse 69

"So consume what you have taken of war booty [as being] lawful and good, and fear Allah.. Indeed, Allah is Forgiving and Merciful."

Chapter 20, Verse 81

"[Saying], "Eat from the good things with which We have provided you and do not transgress [or oppress others] therein, lest My anger should descend uponyou. And heupon whom My anger descends has certainly fallen."”

145

146

147

148

149

150

151

152

153

154

155

156

157

158

159

160

161

162

163

164

165

166

167

168

169

170

171

172

173

174

175

176

177

178

179

180

181

182

183

184

185

186

187

188

189

190

191

192
There are two issues that need to be considered, firstly, interpreting Toyyiban and secondly, interpreting whether Halal and Toyyiban are intertwined or not. Sirjuddin et al. (2013), brings out that at present the term "Halalan Toyyiban" is not officially used and exposes gaps in interpreting the concept. They propose an approach to interpret "Halalan Toyyiban", that instead of using single verses, all the verses from the Qur'an on the topic should be used to get a more holistic approach (Sirajuddin, et al., 2013). At present some interpretations portray Toyyiban as nourishing, safe, hygienic and of good quality (Arif \& Ahmad, 2011; Hashimi, et al., 2010; Afifi, et al., 2013; Badruldin, et al., 2011). Saifuddeen and Salleh (2013) based on both the Qur'an and the Sunnah proclaim that an aspect of Toyyiban is food safety (Saifuddeen \& Salleh, 2013). Rahman et al. (2014) relate the concept to food ethics, with the main issues being safe food, animal welfare and environmental protection. Arif and Sidek (2015) describe Toyyiban as clean, without any impurities, derived from a halal source, not causing pain and misery to people consuming it and consisting of nutritious and beneficial elements. The current study analyses the Halal and Toyyiban from a food safety perspective.

With regards to the second issue, some authors referred to "Halalan Toyyiban" as a combined approach (Samori, et al., 2014; Abdul, 2014; Samori \& Sabtu, 2014; Badruldin, et al., 2011; Omar, et al., 2014; Arif \& Ahmad, 2011; Ambali \& Bakar, 2014; Omar, et al., 2013; Kassim, et al., 2014; Afifi, et al., 2013) (Said, et al., 2014; Shallah \& Hussin, 2013; Zakaria, 2008; Arif \& Sidek, 2015; Din \& Duad, 2014; Talib, et al., 2010; Nakyinsige, et al., 2012). Arif and Ahmad (2011) cite different Islamic scholars, asserting that the concept of Toyyiban and Halal are intertwined. Furthermore, it has been stated in the World Halal Forum that Halal products are universal products and they should have high standards regarding quality, safety, packaging and labelling (WHF, 2009). In addition, a study reports that Good Hygiene Practices (GHP) and Good Manufacturing Practices (GMP) are compulsory requirements in Halal food preparation (Rahman, et al., 2014). Islamic Manufacturing Practice (IMP) approach based on "Halalan Toyyiban” is also being suggested (Nasaruddin, et al., 2011).

On the other hand, in some studies Toyyiban assurance is handled as a separate entity from Halal assurance (Batu \& Regenstein, 2014; Mohamed \& Backhouse, 2014; Riaz \& Chaundry, 2004; Yunus, et al., 2010) and refer to CAC standards, the UK food law, EU general food law or the HACCP systemfit to cover the Toyyiban aspect (Tieman, 2013; Mohamed \& Backhouse, 2014). Batu \& Regenstein (2014) raised a question on how involved the Halal certification bodies would become regarding Toyyiban (Batu \& Regenstein, 2014). This view might be further emphasised with the statement of Riaz \& Chandry (2004) that, although, safe food and hygienic production is a base for Halal production, at present food safety is the responsibility of government agencies and organizations such as the United Nation's Food and Agriculture Organization (FAO) and World Health Organization (WHO) (Riaz \& Chaundry, 2004). This approach might lead to a situation where products certified as Halal may not be safe or of prescribed quality or in other words not be Toyyiban (Arif \& Ahmad, 2011).

Furthermore, for example, from a governmental point of view, Atalan-Helicke (2015) noted, that the Turkish Standards Institute, a governmental institute responsible for various standards, declared that food safety issues would have precedence over religious concerns and added that the secular state office could only decide on halal status of food (Atalan-Helicke, 2015). Little is known about governments' approaches, so further research is needed on how governments interpret and handle food safety and Halal issues.

It is also interesting to note, that according to the Malaysian Government Trade Description Act 1972 Halal should be non-toxic or injurious to health (Malaysia government, 2011). The MS 1500:2009 states that Halal food should be safe for consumption, non-poisonous, non-intoxicating or non-hazardous to health (Department of Standards of Malaysia, 2009). On the other hand, the CAC/GL 24-1997's definition of Halal does not include a clause on safety. It just refers to following Codex General Principles on Food Hygiene and other relevant Codex Standards during Halal food production (CAC, 1997). This suggests that the Malaysian government and the Malaysian standard MS 1500:2009 have a unified "Halal Toyyiban” approach whereas the Codex guidelines refers to Halal and Toyyiban independently. Different interpretations of a unified "Halalan Toyyiban” approach are also illustrated by a study conducted by Latif et al. (2014), which gives 
further insight to Halal assurance by comparing nine certification bodies and their standards all of which had 7 aspects in common:

1) the premises must be clean and not contaminated;

2) qualified Muslims must slaughterall birds and animals;

3) facilities and equipment must not be contaminated by non-Halal items;

4) only Halal ingredients could be used for Halal products;

5) animal-based ingredients must be derived from Halal animals that have been slaughtered in accordance with the Islamic law;

6) packaging materials must not contain unlawful and harmful ingredients;

7) there must be no contamination between Halal and non-Halal products during storage handling, transporting and manufacturing (Latif, et al., 2014);

Regarding food safety aspects the important points are 1), 3) and 6). This shows something of an overlap between Halal and food safety assurance activities. When comparing nine Halal standards, only four of nine demanded compliance with Good Manufacturing Practice (GMP) and Good Hygiene Practice (GHP) and two out of nine demanded HACCP (Latif, et al., 2014). The HACCP system referred to was used for food safety assurance, not Halal assurance. From those nine standards the MS 1500:2009 has the highest number of requirements, including reference to GMP, GHP and/or HACCP, which should be fulfilled in order to be Halal certified. (Latif, et al., 2014). However, the study includes a limited number of certification institutions, so no final conclusions could be made on a global level on the most comprehensive certifications and on food safety coverage in Halal standards.

Instead of having one common standard, Halal CBs have their own standards and certification requirements demonstrating variance in interpreting the "Halalan Toyyiban” concept (Latif, et al., 2014). As it could be seen, at present the interpretation of the Qur'an and Sunnah regarding halal and food safety is being done by different entities - scholars, governments, standards' makers and certifiers.

In addition, in recent years popular magazines (like The Halal Journal and Standard and Quality News) and authors have started to refer to halal as a benchmark for safety, hygiene and quality without a proper reference (Nasaruddin, et al., 2011; Mohtar, et al., 2014; Muhammad, et al., 2009; Abdullah, et al., 2007; Talib, et al., 2008; Tahir, et al., 2015; Aziz \& Sulaiman, 2014; Marzuki, et al., 2012; Khalek, 2014; Said \& Elangkovan, 2013). This is a worris ome trend, because without an official and globally accepted approach, it might lead to wrong perception and awareness of the Halal concept. Furthermore, recent Islamic economy reports highlight Toyyiban as a new trend and a marketing opportunity and even refer to Toyyiban as a possible value adding factor (International Trade Centre, 2015; Thomas Reuters, 2013), showing separation of the two concepts in the current Halal food market.

It is clear, that the word "Toyyiban" does not have a distinct format and is used in several different forms, like thoyyiban, tayyab, tayyaban, toyyib, etc. The scope of Toyyiban needs to be determined and officially acknowledged, may it be animal welfare, quality, safety or nutritious characteristics. It should be clear to all parties and might even be used to ascertain clarity and extend the scope of Halal assurance. For example, using the definition "Halal" for products meeting the main Halal requirements and "Halal \& Toyyiban" for products meeting both Halal and wholesomeness requirements. Only then would it be possible to form universal guidelines and standards. There could be one or multiple standards but they should have clearly defined and globally accepted requirements.

Further research is required to determine why Halal standards and certifications are so differently constructed with regards to food safety and who should or are expected to take responsibility for Toyyiban food safety aspects. Interpretation differences of the "Halalan Toyyiban" concept might be a contributing factor, however it might also be assumed, that governments and the food industry take responsibility for food safety assurance, thus leaving it out from Halal standards' requirements. Dalen and Waarden (2012), brought out that halal certifiers, with regards to Halal standards, are referring to different normative (like cost, technology, reputation, ethnicity and generation), and even emotional values and quality-dimensions, thus creating the predisposition for multiple Halal standards (Dalen \& Waarden, 2012). Furthermore, the effect of economic pressure, high product demand and technological methodologies are also suggested to be important factors in Halal certification differences, culminating in differences in interpretations on topics like stunning, mechanical slaughtering, control and monitoring. Variations in Halal certification could also be contributed to different social dynamics, like a top-down approach or in other words cooperating with producers and governments or a bottom-up approach, prioritizing scholars'and community’s approach (Harvey, 2010).

According to the CAC/GL 24-1997 the term Halal might be subject to interpretation differences by Islamic schools of law (CAC, 1997). During history many Islamic schools of law have emerged, but four of them have 
remained with the largest amount of followers, these are Hanafi, Maliki, Shafi'i and Hanbali. They are mostly similar with some interpretation differences, which are equally valid, in the areas of belief, religious practice and law, made in the light of needs and realities of their time (Akgündüz, 2010). It has been suggested by Prof. Dr. M. H. Kamali, an Islamic scholar, that since the Islamic schools of law are united in the fundamentals of Islam, these differences should not be insurmountable barriers to a harmonised halal standard (The Halal Journal, 2008). A good example in incorporating different Islamic schools of law is a Turkish Halal certification centre GIMDES, which has also created its own Halal standard. A tick $(\sqrt{ })$ image in the logo can be added beside the schools of law (i.e. Shafi, Hanbali, Maliki, Hanafi) according to which the certified company complies. The certification could be represented by one or even all of them (GIMDES, 2015). Further research needs to be done on what kind of effect could the causes of variations in Halal certification and the different schools of law have on the interpretation and incorporation of the "Halalan Toyyiban" concept and their certification process and whether or not it brings any complications in forming a unified globally accepted Halal standard. There is very little known about how consumers, both Muslims and non-Muslims, perceive the Halal concept with regards to foodstuffs. The studies done so far give little insight on the topic. A study conducted in Malaysia shows, that consumers choose products with Halal logos in search for assurance that the product is suitable for consumption by Muslims (Abdul, et al., 2009). Although a study showed, that Muslim consumers' Halal awareness should be improved in Malaysia (Ahmad, et al., 2013), another showed that a significant amount of the consumers perceive halal as clean, safe and of high quality (Ambali \& Bakar, 2014). Furthermore, two studies also conducted in Malaysia regarding non-Muslims and their Halal awareness showed that they perceive Halal to incorporate issues like food safety and environmental friendliness aspects (Golnaz, et al., 2010; Golnaz, et al., 2012). Although, the studies are not globally generalizable, they suggest an understanding of food safety assurance intertwined with the Halal concept from the consumers' perspective. The present global Halal assurance situation could lead to a situation, where consumers might not get what they are expecting when purchasing a Halal product, which might lead to contradiction in Muslims' religious practices. Therefore, it is necessary to reach an official unified Halal approach and according to that raise consumers' awareness ultimately satisfying the needs of Muslims globally.

\subsection{Halal Assurance - The Current Situation}

Lack of uniformity in Halal standards, weak enforcement and the confusing variety of Halal-logos make it difficult for consumers today to make qualified and informed choices (WHF, 2013; Latif, et al., 2014). Worldwide there are variations in the Halal food industry in Halal requirements, Halal assurance activities (Spiegel, et al., 2012) and a lack of a proper accreditation systemto oversee Halal CBs' activities rendering more active and influential institutions both certifiers and supervisors leading to a potential conflict of interests (International Trade Centre, 2015; Halim \& Salleh, 2012). In addition to multiple Halal certification agencies in a country (Halim \& Salleh, 2012; Harvey, 2010; Batu, 2012), variations in countries' Halal legislation cause further Halal assurance confusion (Halim \& Salleh, 2012), e.g. conflicts with the Technical Barriers to Trade (TBT) and the Sanitary and Phytosanitary Measures (SPS) agreements in trade (Atkearney, 2009). From 2004 specific trade concerns regarding SPS and TBT Agreements about Halal requirements have risen mainly between non-Muslim and Muslim countries, however, also between Muslim countries, namely Turkey and Malaysia (WTO, 2015; WTO, 2015).

To simplify Halal assurance in the global Halal food industry alternative suggestions like removing pig and its derivatives have been suggested (Tieman \& Hassan, 2015), in addition to not using the istihalah (could be defined as irreversible transformation of materials to other materials) concept in Halal certification to avoid further ambiguity. Namely, the concept of istihalah is prone to different interpretations by Muslim scholars, resulting in varied acceptance of products (Jahangir, et al., 2016; Jamaludin, et al., 2011; Bin Mohamad, et al., 2012; Farouk, et al., 2016).

There have been various attempts to make one global or at least a renowned Halal standard, for example by Association of Southeast Asian Nations (ASEAN), the Standards and Metrology Institute for Islamic Countries (SMIIC) established by the Organisation of Islamic Cooperation (OIC), the International Halal Integrity Alliance (IHIA) or the recently disbanded Halal food project committee of the European Committee for Standardization (CEN) who were working on a European Halal Standard (Dağ \& Erbasi-Gonc, 2013; Abdul, et al., 2009; IHIA, 2015; International Trade Centre, 2015; Kayadibi, 2014; CEN, 2016). In addition, the latest progressions include developments like the Emirates Authority for Standardisation \& Metrology of United Arab Emirates (ESMA) proposing to the ISO members to set up an ISO Halal standard (ESMA, 2015).

Malaysia, a member of the OIC, aims to strengthen its Halal food industry and strives to develop a global Halal hub with their Third Industrial Malaysia Master Plan (IMP3 2006-2020) (MITI, 2006). Already, the Malaysian standard MS1500:2009 is widely accepted by OIC members (Arif \& Sidek, 2015). However, other OIC member countries such as Turkey, Pakistan and United Arab Emirates have also showed interest in promoting their own Halal certification (Rahman, et al., 2013; Rahman, et al., 2014). The Pakistan Standards Quality and Control 
Authority (PSQCA) established the Technical Committee on Halal Food Standards which formed the Pakistan Standards (PS) - PS 3733: 2010 Pakistan Standards for Halal Food Management Systems: Requirements for any organisation in the food chain, PS 4992: 2010 Pakistan Standard for General Criteria for the operation of Halal Certification Bodies and PS: 5142: 2013 Conditions for Halal Food Conformity Assessment Bodies (Afzal, n.d.; Lateef, n.d.; PSQCA, 2013). Competition between associations (Atalan-Helicke, 2015; International Trade Centre, 2015) and countries could be one of the reasons why a globally recognised Halal standard has not yet emerged from the suggested standards, e.g. in 2011 and 2012 in WTO meetings Turkey invited Malaysia to participate in the OIC's initiatives in developing a common standard, without any initiative from Malaysia's side (WTO, 2012).

Furthermore, many countries do not have a regulatory body to control whether the products on the market labelled as Halal are really so (Bonne \& Verbeke, 2008; Harvey, 2010; Halim \& Salleh, 2012). Even if a country has a necessary regulatory body, enforcement poses serious challenges (Halim \& Ahmad, 2014). Halal control and monitoring could include procedures like continuous monitoring, regular audits or a combined approach of audits and laboratory tests (Harvey, 2010; Spiegel, et al., 2012; Farooqui \& Kurt, 2013). Deficiencies in monitoring and control make it hard to prove whether the food production companies located elsewhere than the certifier's country are following halal requirements even after they have been awarded the certificate and no longer feel pressure by the certification process (Ambali \& Bakar, 2014). Even for the MS 1500:2009 with its governmental support, establishing valid monitoring and control systems poses challenges (Abdul, et al., 2009; Ambali \& Bakar, 2014). Ambali and Bakar (2014) conclude that governmental legislation or a global Halal authority would be a way of tackling the problem of fake halal certificates from unreliable sources and would bring Halal compliancy to a more significant level.

Since, a number of OIC member countries are lacking a Halal CB, Halal import regulations and/ora domestic Halal Act (Halim \& Salleh, 2012), it raises an issue on how products imported to Muslim countries are being monitored and whether Halal compliance is really being assured. For example, in the Gulf Cooperation Countries (GCC), a high percentage of food is being imported, which mainly arrives at UAE and is then reexported to the rest of the GCC and other countries (Al-Kandari \& Jukes, 2011; Al-Kandari \& Jukes, 2009). Generally, in Muslim countries products are assumed to be Halal, if they are not marked otherwise (Ireland \& Rajabsadeh, 2011; Ahmad, et al., 2013). In a region in Turkey only 6\% of the survey's participant paid attention to Halal marking on a product's package (Aktas, et al., 2009). A study showed that the consumers in the United Arabic Emirates (UAE) have concerns about some product categories, that they might not be Halal (Ireland \& Rajabsadeh, 2011). For example, meat products (hamburgers, beef and sausages) caused great concern, that they could be dirty or contaminated with pork. The word "dirty" was not further elaborated on. These results are concerning, because they show that current government regulations (even in a Muslim-majority country) are not enough for consumer assurance that the products on the market are Halal. However, the authors stated that this study is the first of its kind and this area clearly need some further research, so at this point it is difficult to make generalisations (Ireland \& Rajabsadeh, 2011). However, it is worthy of note that, just recently, it was announced that the UAE is preparing a new food law to tighten the control on the food supply chain, including ministry's approval upon importing and prohibiting false or incorrect labelling (Salama, 2015).

Although some research has been done on the food safety systems in the GCC countries, more needs to be done on Muslim-majority countries' food safety control systems (Al-Busaidi \& Jukes, 2014; Fernando, et al., 2014). A study on food control systems in GCC showed that although their systems have improved, they are still insufficient to provide necessary protection. Deficiencies of foodborne disease surveillance and inspection were brought out and that food inspection relies mostly on end product testing (Al-Kandari \& Jukes, 2009). Very recently a study was conducted about the governmental food safety systems in Sultanate of Oman (Al-Busaidi \& Jukes, 2014). The study revealed a lack of sufficient food safety systems at the governmental level. The government would need to establish strong food safety measures like making the HACCP systemmandatory to all food production companies to have a system in place for the prevention of foodborne diseases (Al-Busaidi \& Jukes, 2014). UAE and Saudi Arabia in recent years have shown dedication in trying to implement HACCPbased food control systems (Al-Kandari \& Jukes, 2011; Al-Kandari \& Jukes, 2012). Additionally, Kuwait's food safety systemrequires further improvement especially in ensuring food laws are more preventative in nature and to enforce proper food inspection (Al-Mazeedi, et al., 2012). In Malaysia the Food Hygiene Regulation (2009) was released and Malaysia's attempts for ensuring compliance among food industries with the food regulation are still ongoing (Fernando, et al., 2014). A study states, that Malaysia, Singapore, Indonesia and Thailand have comprehensive food legislation. Enforcement activities, however, need further research (Ismail, 2011).

This demonstrates that, even though the Halal concept may encompass food safety, the Muslim majority countries might lack systems and enforcement activities for guaranteeing it. When food safety is efficiently controlled and regulated by governments it would be a strong prerequisite in which a solid Halal assurance 
systemcould be built. If the companies in the Muslim-majority countries are assumed to produce Halal products even without Halal certification they might also be assumed to assure food safety. Further research is necessary on how food production companies in Muslim-majority countries assure food safety and whether they perceive food safety as a part of Halal requirements.

The unification of standards should be taken as the first milestone, only then would it be possible to start working on proper certification, controlling and monitoring procedures and give necessary support to policy makers to move forward in the field of regulating Halal in both Muslim and non-Muslim countries.

\subsection{The Malaysian Standard and Food Safety Principles}

Malaysia was the first to establish Halal laws (Riaz \& Chaundry, 2004). The Malaysia’s Trade Description Act 1972 defined Halal to protect its label and determine punishments against falsifying Halal documentation (Malaysia government, 2011). At present, however, Malaysia’s Halal food sector is facing various Halal assurance barriers (Talib, et al., 2010) and challenges culminating with halal governance hindering the certification process (Majid, et al., 2015).

MS 1500:2004 made Malaysia the first country to issue such a standard for manufacturing, preparation, management and storage of Halal foods (Abdul, et al., 2009). The $2^{\text {nd }}$ revision of the standard was launched in 2009 with additional requirements, such as management responsibility and demands for premis es having more emphasis on food hygiene and safety (Department of Standards of Malaysia, 2009). However, in the 2004 standard it is stated, that the standard should be used together with MS 1480 (Food safety according to hazard analysis and critical control point (HACCP) system), MS 1514 (Good Manufacturing Practice (GMP) for food) standards and that governmental guidelines on good hygiene practice for small and medium scale food industries towards HACCP should be followed (Deparment of Standards Malaysia, 2004). In the second revision these are made voluntary and the industry is given a chance to choose the type of prerequisites they want to use to ensure food safety. This would seem to be a retrograde step in terms of assuring best practice food safety management approaches as a part of Halal certification.

The CAC/RCP 1-1969 gives guidelines for the production of safe food suitable for consumption. It covers the food chain from primary production to the consumer. It encompasses general principles for ensuring food safety, which every company being a link in the food chain should implement (CAC, 2003). The MS1500:2009 is a standard organized by a government of a Muslim-majority country wishing to be renowned in the world in the area of Halal. Although, the Malaysian Halal certification system might lack operational efficiency it is still at present a world renowned Halal standard (Noordin, et al., 2009). The MS 1500:2009 will be evaluated against the CAC/RCP 1-1969 to see if the basic food safety activities are incorporated in it.The MS 1500:2009 brings out that Halal food should be safe for consumption, non-poisonous, non-intoxicating or non-hazardous to health. An important paragraph in the standard regarding food safety assurance is Section 3.4 titled "Hygiene, sanitation and food safety". It states that "Hygiene, sanitation and food safety are prerequisites in the preparation of halal food" and "Halal food shall be processed, packed and distributed under hygienic conditions". This shows that food safety is considered as a part of Halal assurance or in other words they consider food safety aspects of Toyyiban as part of the Halal concept, even though this term is not used in the standard. Therefore, the MS1500:2009 should take necessary precautions to fulfil food safety requirements in order to comply with the food safety criteria.

A study states, that the MS1500:2009 in its entirety is consistent with the "Halalan Toyyiban" concept, however taking a different approach referring to MS 1480:2007 and Food Acts and Regulations as food safety aspects, categorizing the 3.4 chapter as a parameter for food cleanliness (Arif \& Sidek, 2015). However, the MS 1480:2007 being voluntary and shortcomings in legislation implementation (Duad, et al., 2011) undermine this approach. This means, that in order for MS1500:2009 to assure "Halalan Toyyiban", the standard itself should incorporate food safety requirements. Although, implementation of the standard could also be lacking among producers (Duad, et al., 2011; Din \& Duad, 2014), at least the "Halalan Toyyiban” concept would be under control of one institution and hence also the responsibility of the producers, who could in turn commit to implementing "Halalan Toyyiban" as a wholesome approach. A situation where a producer is committed to implement the Halal standard, which does not include sufficient food safety requirements, might lead to deficiencies in the wholesomeness of the "Halalan Toyyiban" concept, if the producer is not also committed to implement food safety legislation. Therefore, a standard, aiming to capture the "Halalan Toyyiban" concept in its entirety, should not be separated into pieces and scattered between different institutions. In other words, as "Halalan Toyyiban" has a wholesome approach, thereof the corresponding standard should have it as well. Therefore, this study analyses the food safety aspect of "Halalan Toyyiban" in the MS1500:2009, with the aim to identify shortcomings from a wholesome approach. In addition, in the Arif and Sidek (2015) study analysis and interviews with auditors were conducted, however on-site audits were not carried out in JAKIM's Halal certified establishments, which would have shown, whether or not the "Halalan Toyyiban" requirements were 
applied in practice and whether the approach of scattered requirements with responsibility to different institutions would have been viable or not (Arif \& Sidek, 2015).

An important statement made in the MS 1500:2009 is that where necessary, suitable detection or screening devices should be used, which is also word by word prescribed by the CAC/RCP 1-1969. Furthermore, in order for premises to comply with GMP and GHP requirements, MS 1500:2009 also suggest the standards MS 1480 and MS 1514 as a way to comply with these criteria; however these additional standards are voluntary. This rais es a question of the certification process, that since many GMP and GHP guidelines exist, how audits would be conducted to evaluate that the food safety criteria are complied with at a necessary level, i.e. at the level described by CAC/RCP 1-1969. The standard also states that the premises must be licensed in accordance with public health legislation currently in force by the competent authority in Malaysia. As a national standard, the guideline tailors to local food industries and could further be expanded to achieve global acceptance. This would also mean that during the certification process the aforementioned regulations should also be strictly audited. These regulations are compulsory for local producers, and governmental support and technical assistance are provided for them to acquire the Halal certification. For exporters to Malaysia this makes their situation more complicated as they will have to abide by the local public health legislation. However, exporters from countries with recognised Halal CB and with a certificate from them will be accepted by the Malaysian government. Finally, it is not clear whether the legislation compliance is audited by the certification agency or by the governmental officials. This is especially important for exporters, whose production facility does not reside in Malaysia. With regards to meat and products of animal origin the Malaysian Department of Veterinary Services inspects aspects of food safety assurance, whereas JAKIM inspects only compliance with Halal requirements (DVS, 2015). Therefore, food safety is mainly assured by the government limiting JAKIM's authority by rendering food safety requirements secondary with regards to the MS 1500:2009 standard.

It is also brought out in the standard that it may not contain all requirements. Exporters and local producers alike should be provided with technical assistance in interpreting the MS 1500:2009, as it does not specify exactly what legislation would be compulsory under the current standard. In the bibliography the main laws regulating food (Food Hygiene Regulation 2009, Food Regulation 1985 and Food Act 1983) are specified, but are not mentioned anywhere else in the standard. For exporters, the last two regulations are mandatory (USDA, 2011), which leaves a question on whether the Food Hygiene Regulation 2009 would also be mandatory when applying for the MS 1500:2009 standard.

According to the Islamic law najis means dirtiness which includes things that are naturally and non-naturally najis. The latter are things that have become najis upon contact with it and could be purified (The Central Islamic Committee of Thailand, n.d.). MS1500:2009 states that Halal food does not contain and does not come into direct contact with anything regarded as najis, including devices, utensils, machines, equipment, processing aids and packaging materials contaminated with or containing najis. According to the standard dogs and pigs and their descendants, any liquid and objects discharged from the orifices of human beings or animals such as urine, blood, vomit, pus, placenta and excrement, sperm and ova of pigs and dogs, carrion or halal animals that are not slaughtered according to Islamic law, alcoholic beverages, intoxicants and food or drink which is mixed with them are considered naturally as najis. It is also important to note, that feces, urine and vomit are also possible sources of food-borne disease, which need food safety measures to avoid food contamination (FDA, 2012).

In the comparis on it was clear that some of the basic principles of food hygiene were considered. The MS 1500:2009 briefly summarises the requirements for the production of safe food, but they are not further elaborated in detail. Table 2 gives an overview of the points that are generally covered in the MS 1500:2009, where these general statements are aligned with equivalent, whereas more detailed, guidelines of the CAC/RCP 1-1969. Table 3 cites the requirements in the CAC/RCP 1-1969, which are lacking in the MS 1500:2009.

Like the CAC/RCP 1-1969, the MS 1500:2009 also intends to cover the entire supply chain from requirements on animal health to packaging, labelling and transportation. In the MS 1500:2009 it was brought out that Halal manufacturers shall implement measures for: 1 ) inspection and sorting of raw materials, ingredients and packaging material before processing; 2) waste management; 3) harmful chemical storage requirements; 4) foreign body management; 5) prevention of excessive use of permitted food additives. The MS 1500:2009 quite thoroughly covers the requirements on premises, i.e. it emphasises that the premises should not be situated near a pig farm, but it does not consider other potential sources of contamination. In addition to the above mentioned five requirements, other fairly well covered areas are packaging, management and supervision, transportation requirements, product information and consumer awareness. Although, the MS 1500:2009 brings out waste management, it does not give further guidelines on what is the acceptable level of practice.

In relation to management and supervision the MS 1500:2009 states that a Muslim Halal executive officer should be appointed or a Muslim committee should be established, who should have knowledge on Halal 
principles for the purpose of implementing a Halal control system. However, there is a lack of a food safety approach, for example CAC/RCP 1-1969 states that managers and supervisors should have sufficient knowledge of food safety to notice risks and lead preventative, corrective and monitoring activities. In order to assure food safety the Muslim Halal executive or the committee should also have basic knowledge of food safety and make sure that the managers and supervisors on every level of the company would be aware of both the main Halal and food safety requirements.

Table 2. Food safety requirements in the CAC/RCP 1-1969 and their more general MS 1500:2009 equivalents.

\begin{tabular}{|c|c|c|}
\hline TOPIC & CAC/RCP 1-1969 & MS 1500:2009 \\
\hline \multicolumn{3}{|c|}{ Establishment: Equipment } \\
\hline $\begin{array}{l}\text { Food control and } \\
\text { monit oring }\end{array}$ & $\begin{array}{l}\text { Equipment used to cook, heat treat, cool, store or freeze food should be } \\
\text { designed to achieve the required food temperatures as rapidly as necessary }\end{array}$ & \multirow{3}{*}{$\begin{array}{l}\text { 3.4.1 Hygiene, sanitation and food } \\
\text { safety are prerequisites in the } \\
\text { preparation of halal food. It includes } \\
\text { the various aspects of personal } \\
\text { hygiene, clothing, devices, ut ensils, } \\
\text { machines and processing aids and the } \\
\text { premises for processing, } \\
\text { manufacturing and storage of food. }\end{array}$} \\
\hline equipment & $\begin{array}{l}\text { in the interests of food safety and suitability, and maintain them } \\
\text { effectively. }\end{array}$ & \\
\hline $\begin{array}{l}\text { Temperature } \\
\text { control }\end{array}$ & $\begin{array}{l}\text { Depending on the nature of the food operations undertaken, adequate } \\
\text { facilities should be available for heating, cooling, cooking, refrigerating } \\
\text { and freezing food, for st oring refrigerated or frozen foods, monitoring } \\
\text { food temperatures, and when necessary, controlling ambient temperatures } \\
\text { to ensure the safety and suit ability of food. }\end{array}$ & \\
\hline
\end{tabular}

Cleaning Adequate facilities, suitably designated, should be provided for cleaning food, utensils and equipment.

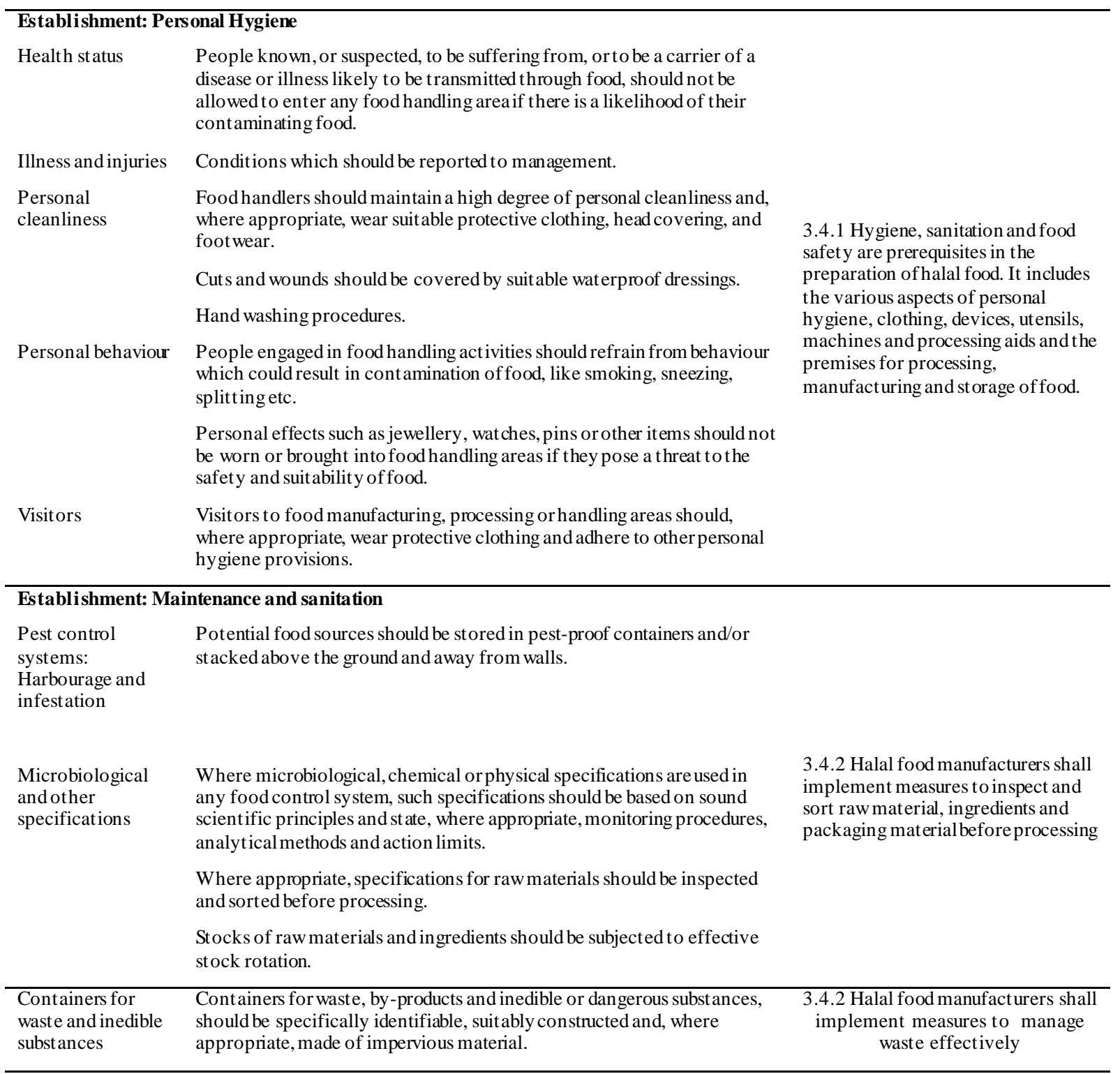




\begin{tabular}{ll}
\hline $\begin{array}{l}\text { Control of } \\
\text { operation: }\end{array}$ & $\begin{array}{l}\text { Adequate drainage and waste disposal systems and facilities should be } \\
\text { proinage and }\end{array}$ \\
waste disposal & \\
\hline
\end{tabular}

As seen in Table 2 requirements on equipment, personal hygiene and pest harbourage and infestation are encompassed in the MS 1500:2009 standard in a more general manner. These are summarised under the MS paragraph 3.4.1 with a statement that hygiene, sanitation and food safety include "various aspects of personal hygiene, clothing, devices, utensils, machines and processing aids and the premises for processing, manufacturing and storage of food". The CAC/RCP 1-1969 gives specific guidelines on what should exactly be done to comply with these categories. Since the MS 1500:2009 states that Halal food should not be contaminated with human urine, blood and vomit etc., it is suggested that the personal hygiene section should be further elaborated to contain detailed guidelines to ensure full compliance by the industry. This is because staff working in direct contact with food products and who do not wash their hands thoroughly and correctly after going to the toilet, after vomiting or did not take necessary precautions after an injury, would render the product non-halal if faecal, vomit or blood contamination were to occur. This would be considered as a serious violation of halal requirements and should be subject to strict precautionary methods like control, monitoring and employee education.

Regarding raw materials, ingredients and packaging materials control before processing, the CAC/RCP 1-1969 brings out the necessity of specifications. MS 1500:2009 does not mention this, which is interesting because appropriate raw materials are the foundation to Halal assurance. Raw material intake, control and non-Halal ingredient verification should be thereof very strictly regulated. A way to prove Halal assurance would be with products' specifications.

In Table 3 it can be seen that the MS 1500:2009 does not include water, air quality and ventilation and lighting requirements. Temperature control and microbiological growth are also important factors not elaborated by the MS 1500:2009. Inadequate food temperature control is one of the most common causes of foodborne illness or food spoilage (CAC, 2003). These might directly influence the Halal status of food when food is contaminated with pathogenic microorganism or they grow to numbers that might cause illness hence jeopardizing the Halal status of the product. The standard mentions perishable foods only with regards to loading docks.

The MS 1500:2009 does not cover documentation and recall procedures, which would be essential to prove that both food safety and Halal are assured and would enable quick withdrawal from the market and if necessary alerting the public of non-Halal products that might be wrongly perceived as Halal by consumers. Furthermore, in the MS 1500:2009 the importance of cleaning is being emphasised, however, suitable cleaning programs or cleaning verification are not specified. The MS 1500:2009 states that pests are considered non-Halal and should be subject to strict precautionary methods. However, it does not mention pest surveillance and that pest infestation should be dealt with immediately. The MS 1500:2009 does not cover personnel training to raise workers' awareness on Halal and food safety and, surprisingly, does not require specific training for nonMuslim personnel about the general principles of Halal and specific requirements for cross-contamination with Haram.

Although the MS 1500:2009 highlights some food safety requirements, these should be more thorough to ensure proper food safety assurance. In addition, there seems to be somewhat of an overlap between Halal and food safety requirements, like personnel hygiene, pest management, cleaning procedures and raw material specifications. These aspects should be described more thoroughly to ensure Halal and Toyyiban assurance.

Table 3. The requirements in the CAC/RCP 1-1969, which were lacking in the MS 1500:2009.

\begin{tabular}{ll}
\hline AREA & CAC/RPC 1-1969 REQ UIREMENTS (CAC,2003) \\
\hline Control of production & \\
Water requirements & $\begin{array}{l}\text { An adequate supply of potable water with appropriate facilities for its st orage, distribution and } \\
\text { temperature control, should be available whenever necessary to ensurethe safety and suit ability of } \\
\text { food. Only potable water should be used in food handling and processing. }\end{array}$ \\
Temperature control & $\begin{array}{l}\text { Systems should be in place to ensure that temperature is controlled effectively where it is critical to } \\
\text { the safety and suit ability of food. }\end{array}$ \\
Air quality and ventilation & Adequate means of natural or mechanicalventilation should be provided. \\
Lighting & Adequate natural or artificial lighting should be provided to enable the undertaking to operate in a \\
& hygienic manner.
\end{tabular}




\begin{tabular}{ll}
\hline Documentation and records & $\begin{array}{l}\text { Where necessary, appropriate records of processing, production and distribution should be kept and } \\
\text { retained for a period that exceeds the shelf-life of the product. } \\
\text { Recall procedures }\end{array}$ \\
$\begin{array}{l}\text { Managers should ensure effective procedures are in place to deal with any food safety hazard and } \\
\text { to enable the complete, rapid recall of any implicated lot of the finished food from the market. }\end{array}$ \\
$\begin{array}{ll}\text { Cleaning programmes } & \begin{array}{l}\text { Cleaning and disinfect ion programmes should ensure that all parts of the establishment are } \\
\text { appropriately clean, should include the cleaning of cleaning equipment and be continually and } \\
\text { effectively monitored for their suit ability and effectiveness and where necessary, documented. }\end{array} \\
\text { Monitoring effectiveness } & \begin{array}{l}\text { Sanitation systems should be monitored for effectiveness, periodically verified by means such as } \\
\text { audit pre-operational inspections or, where appropriate, microbiological sampling of environment } \\
\text { and food contact surfaces and regularly reviewed and adapted to reflect changed circumstances. }\end{array} \\
\text { Pest control systems: Monitoring and } & \begin{array}{l}\text { Establishments and surrounding areas should be regularly examined for evidence of infestation. } \\
\text { detection }\end{array} \\
\text { Pest control systems: Eradication } & \begin{array}{l}\text { Pest infestations should be dealt with immediately and without adversely affecting food safety or } \\
\text { suitability. }\end{array} \\
\text { Training } & \begin{array}{l}\text { All personnel should be aware of their role and responsibility in protecting food from } \\
\text { contamination or deterioration. Food handlers should have the necessary knowledge and skills to } \\
\text { enable them to handle food hygienically. }\end{array} \\
\text { Awareness and responsibilities } & \text { Assessing the level of training required. } \\
\text { Periodic assessments of the effectiveness of training and instruction programmes should be made. }\end{array}$ \\
$\begin{array}{l}\text { Training programmes } \\
\text { Refresher training }\end{array}$
\end{tabular}

\subsection{Using the HACCP system for Halal Assurance}

The HACCP systemis a recommended approach to enhance food safety from farm to fork. It is a preventative systemto deter food safety violations, through identifying, controlling and monitoring hazards (CAC, 2003). In addition, there are suggestions that it could be used to assure Halal compliance (Riaz \& Chaundry, 2004; Spiegel, et al., 2012; Dahlan, et al., 2013; Kohilavani, et al., 2013; Kohilavani, et al., 2012; Bonne \& Verbeke, 2008; Kamaruddin, et al., 2012; Omar, et al., 2013; Ruzevicius, 2012; Ceranic \& Božinovic, 2009). At present when HACCP is incorporated in Halal standards it is referred to more as a system of assuring food safety (Latif, et al., 2014).
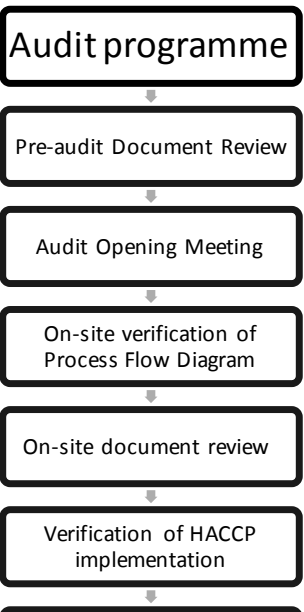

Closing meeting

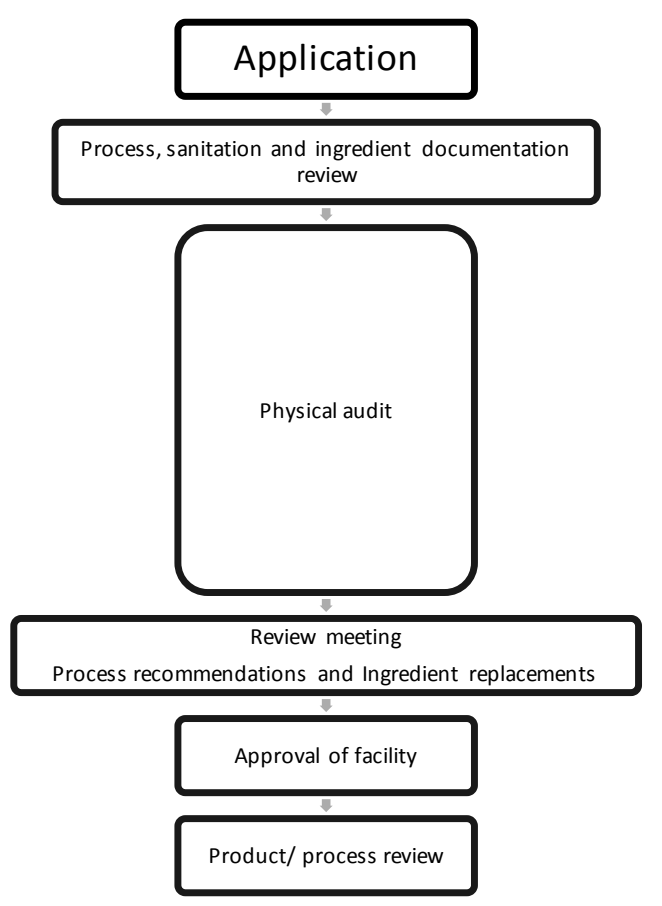


(Riaz \& Chaundry, 2004), Halal Critical Point (JAKIM, 2012), Haram Critical Point (LPPOM MUI, 2008), Halalan Toyyiban Critical Control Points (HTCCP) (Omar, et al., 2013; Omar, et al., 2013), Halal Compliance Critical Control Points (HCCCP) (Kamaruddin, et al., 2012; Kamaruddin, et al., n.d.), Halal Assurance Point (HAP) (Hakim, 2013) and Halal CCP or Sharia CCP (Zikrullah, 2014; Al-Mazeedi, 1996). Similarly the systems have been described variously as Halal Assurance System(HAS), Halal Pre-requisite Programme (Halal PRP) (Farooqui \& Kurt, 2013) and Haram Analys is Critical Control Points (HrACCP) system (Ruzevicius, 2012; Ceranic \& Božinovic, 2009).

In 1996 a Halal assurance systemwas proposed to McDonald's International and named after that as the McHalal System (Al-Mazeedi, 1996). It suggested using the HACCP system for Halal assurance and even determined CCPs, which are all related to meat processing and storing characteristics (Al-Mazeedi, 1996). Kohilavani et al. (2012) proposed a decision tree based approach for the purpose of identifying Halal Critical Control Points. However, it is dedicated for Halal slaughtering. The concept of the Halal-HACCP systemwas taken further by Kohilavani et al. (2013) who discussed the compatibility of the Halal requirements with the HACCP systemby analysing the HACCP steps from a Halal perspective. The study also suggested a decision tree for identifying Halal Critical Control Points for ingredients and process control.

In Thailand, the Halal, Assurance and Liability Quality System(Hal-Q) was developed as a food safety and Halal assurance management system, based on HACCP principles (Dahlan, et al., 2013). However, this research did not give any details on how the Halal assurance was integrated into the HACCP approach. In the study, terms such as "Halal Food Safety", "Halal security” and "Halal Compliance (HC)" were used (Dahlan, et al., 2013). These were not properly defined and are also not widely used in other research, so they would need further elaboration. The study concluded, that there were Halal compliance improvements in Halal and nonHalal certified seafood enterprises (Dahlan, et al., 2013). Since the presence of Haram should have zero tolerance (Kohilavani, et al., 2012; Kohilavani, et al., 2013) the concept of a company having poor Halal compliance remains unclear.

At present two major players in the Halal assurance sector Indonesia and Malaysia have released guidelines for Halal Assurance Systems (HAS) (JAKIM, 2012; LPPOM MUI, 2008), both describing some HACCP system elements, with the main emphasis being on hazard analysis. While the Indonesian version offers an example of the HAS manual and decision trees for critical points' identification, the Malaysian version brings out principles like determining Halal critical control points, making and verifying process flow chart, implementing control measures, developing corrective actions, maintaining documentation, keeping records and verifying. However, more detailed guidance would be necessary to develop a valid "Halalan Toyyiban" based assurance system. While food safety has critical limits, Halal assurance has zero tolerance for Haram, so it should be very clear what kind of cross-contamination would be considered as Haram. However, at present no detailed guidelines exist on what kind of contamination from a GHP breach would be regarded as zero tolerance, e.g. hand washing after using the toilet to prevent faecal contamination. Since faecal contamination is regarded as non-halal (Department of Standards of Malaysia, 2009), a point in production normally regarded as a GHP from a food safety perspective would become a Critical Control Point (CCP), when conducting hazard analysis for Halal assurance. Riaz and Chaundry (2004) incorporated the main Halal requirements and avoiding Haram ingredients into the HACCP system, but did not take into account possible cross-contamination with the potential of turning the produced batch into non-halal because of GMP and GHP violations. Also, a Halal certification case study in a chocolate factory concentrated mainly on the Halal status of the raw materials. (Shariff \& Abd Lah, 2014).

At present no studies have been conducted or evidence provided that the HACCP systemfor Halal assurance is a plausible approach for Halal and Toyyiban assurance. Further research would be needed on this concept's practical use. In addition, globally accepted guidelines, maybe even a CAC standard or guidance document, for the usage of the HACCP system for Halal and Toyyiban assurance should be developed, which should also include clear definition of the main terms and concepts. A master list of hazards of all possible contamination options could be developed, regarding Haram ingredients, Halal requirements, GMP and GHP violation hazards and hazards from the process, which would render the product not suitable for consumption in accordance with Halal and Toyyiban assurance. 


\section{Conclusion}

Halal assurance is increasingly adopted by the global food industries. This can been seen by the growing amount of research conducted on the topic in recent years. However, there are several areas that still need further res earch, e.g. non-Muslimcountries' and manufacturers' perception on Halal assurance, how food production companies and governments in Muslim-majority countries as sure food safety, whether they perceive food safety as a part of Halal requirements and how (or if) Halal assurance is regulated, monitored and controlled in Muslimand non-Muslim countries for import and export goods. These are just some of the topics that need elaboration, in order to detect strengths and limitations of Halal assurance and es tablish a more trustable judicious approach. At pres ent different Halal standards exist, which gives rise to a global challenge for as suring Halal in the supply chain.

Similar to the farm to fork concept which is used in food safety as surance, the same concepts should apply to Halal as surance. However, different interpretations of Halal requirements by Islamic schools of law in addition to different interpretation by standards, guidelines and law makers has paved the way for variations in Halal requirements and certification scope. It is yet to be studied exactly how these factors affect the standardisation process. Without identifying the variables, it is not possible to take themunder control and move toward a more stable framework. The variations in Halal standards put producers in a tight spot, as they might have to get multiple Halal certificates for exporting to different countries. A harmonis ed Halal as surance standard or mutual recognition and acceptance of other Halal certifications by different standard owners would be similar to the Global Food Safety Initiative (GFSI) which emphas is es the 'once certified, accepted every where' concept (GFSI, 2015). Although Halal products are universal products, unlike food safety Halal is not sought everywhere and by all. This makes the Halal assurance process much more fragile due to lack of Halal regulatory bodies, governmental regulation and a unified standardisation system. Hence, monitoring and controlling of Halal products is hard to achieve.

One of the aims of this paper was to determine the position of food safety in the Halal concept. The "Toyyiban" concept, meaning good or wholes ome, seems to be one of the factors playing a role in unifying Halal standards. Some indicate that by default food safety aspects are a part of Halal as surance, whereas others reported that these are two separate and independent entities. First of all, the "Toyyiban" concept should be provided with a proper definition and scope. Next, it should be decided whether it is part of Halal requirements or whether it is a set of separate requirements in the Halal supply chain. One could expand the Halal and Toyyiban assurance schemes by utilising different standards such as "Halal” for products meeting the main Halal requirements and "Halalan \& Toyyiban” for products meeting both Halal and Toyyiban requirements. This would at least clear the confusion of Halal standards being so differently constructed regarding food safety and would enable consumers to make informed decisions, without any breach of religious practices.

A comparis on was conducted between CodexAlimentarius Commission's general principles of food hygiene and the MS 1500:2009 standards. It is noted that there are some food safety requirements in the MS 1500:2009 standard, which seems to embrace the wholeness of Halal and Toyyiban with its requirements for hygienic production and safe products. Even its definition of Halal indicates that, however, further extensions would be necessary to clarify food safety requirements. The standard in a general way makes hygienic production obligatory without making appropriate guidelines and standards mandatory.

The requirements for premises, packaging, management and supervis ion, transportation, product information and consumer awareness were well covered by the MS 1500:2009, with only some minor details lacking. However, personnel hygiene, especially hand washing after toilet usage, pestharbourage and infestations, raw material specifications were referred to quite generally. With regards to protecting the products' Halal status these would also be of paramount importance, as faecal and raw materials contamination with haramproducts will render the food products non-halal.

The HACCP system is considered to be an effective systemfor enhancing food safety. This could alsobe a plausible tool for Halal as surance. However, incorporating Halal features into the HACCP systemis a new concept. Limited research has been done on the topic, which in turn remains general without any detailed guidance. Further research should be done on how food hygiene practices would be crucial for Halal assurance, e.g. hand washing and pest control. In addition, clear definitions for the Halal-HACCP assurance systemare necessary and general guidelines for the systemshould be established to avoid confusion in usage and implementation.

The authors believe that this study has identified many areas for potential research in Halal assurance in the food industry and that it has highlighted critical is sues that were not confronted in previous research. Primary res earch to capture the views of Is lamic scholars from different schools of thought and representatives of different Halal certification bodies should be conducted. Research on Halal assurance is gathering momentumand it is crucial for all to move towards a common goal, an unambiguous disciplined as surance of Halal and food safety requirements in the food chain. 


\section{References}

Abdullah, A., Zubairi, S. I. \& Ghani, M., 2007. Halal Food: Scenario and Current Status in Malaysia. 10th ASEAN Food Conference.

Abdul, M., 2014. Perception of Halal Food Certification in Hat Yai, Thailand. International Journal of Economics and Management, 8(1), pp. 178-194.

Abdul, M., Ismail, H., Hashim, H. \& Johari, J., 2009. Consumer decision making process in shopping for halal food in Malaysia. China-USA Business Review, 8(9), pp. 40-47.

Abdul, M., Ismail, H., Hashim, H. \& Johari, J., 2009. SMEs and Halal certification. China-USA Business Review, 8(4), pp. 22-29.

Afifi, A. H. et al., 2013. Consumer Protection of Halal Products in Malaysia. Middle-East Journal of Scientific research, pp. 22-28.

Afzal, S., n.d. Role of PSQCA in Halal Food Standardization. [Online]

Available at: http://www.halalrc.org/images/Presenations/Shahzad\%20Afzal/Role\%20o f\%20PSQCA\%20in\%20Halal\%20Fo od\%20Standardization.pptx

[Accessed 4 May 2016].

Ahmad, N. A. B., Abaidah, T. N. B. T. \& Yahya, M. H. B. A., 2013. A Study on Halal Food Awareness Among Muslim Consumers in Klang Valley. 4th International Conference on Business and Economic Research (4th ICBER 2013) Proceeding, pp. 1073-1087.

Akgündüz, A., 2010. Introduction to Islamic Law. Rotterdam: IUR Press.

Aktas, N., Bayrak, E. \& Onay, D., 2009. The features taken into consideration by the consumers in Konya, Turkey, when purchasing a food product. Pakistan Journal ofNutrition, 8(11), pp. 1734-1738.

Al-Busaidi, M. A. \& Jukes, D. J., 2014. Assessment of the food control systems in the Sultanate of Oman. Food Control, Volume 51, pp. 55-69.

Al-Kandari, D. \& Jukes, D. J., 2009. A situation analysis of the food control systems in Arab Gulf Cooperation Council (GCC) countries. Food Control, Volume 20, pp. 1112-1118.

Al-Kandari, D. \& Jukes, D. J., 2011. Incorporating HACCP into national food control systems - Analyzing progress in the United Arab Emirates. Food Control, Volume 22, pp. 851-861.

Al-Kandari, D. \& Jukes, D. J., 2012. The food control systemin Saudi Arabia - Centralizing food control activities. Food Control, Volume 28, pp. 33-46.

Al-Mazeedi, H. M., 1996. ASIDCOM. [Online]

Available at: http://www.asidcom.org/IMG/pdf/McHalal System-Dr- Hani M- Al-Mazeedi.pdf

[Accessed 30 October 2015].

Al-Mazeedi, H. M. et al., 2012. Food Safety Review (FSR) in the State of Kuwait as a part of Arab Gulf Area. Internet Journal of Food Safety, Volume 14, pp. 54-69.

Ambali, A. R. \& Bakar, A. N., 2014. People's Awareness on Halal Foods and Products:Potential Issues for Policy-Makers. Procedia - Social and Behavioral Science, Volume 121, pp. 3-25.

Arif, S. \& Ahmad, R., 2011. Food quality standards in developing quality human capital: an islamic perpective. African Journal of Business Management , 5(31), pp. 12242-12248.

Arif, S. \& Sidek, S., 2015. Application of Halalan Tayyiban in the Standard Reference for determining Malaysian Halal Food. Asian Social Science, 11(17), pp. 116-129.

Atalan-Helicke, N., 2015. The halal paradox: negotiating identity, religious values and the genetically engineered food in Turkey. Agric Hum Values.

Atkearney, 2009. The 2009 A. T. Kearney Global Retail Development Index. [Online]

Available at:

https://www.atkearney.com/documents/10192/574489/2009_Global_Retail_Development_Index.pdf/0030907d609d-471a-bdce-335315ff558e

[Accessed 13 December 2015].

Aziz, N. A. \& Sulaiman, S. S., 2014. Role of the Local Authority in Issuing Licence for Halal Certified Premise in the City of Shah Alam. Procedia - Social and Behavioral Sciences, Volume 121, pp. 133-143.

Badruldin, B. et al., 2011. Clients' perception towards JAKIM service quality in Halal certification. Journal of Islamic Marketing, 3(1), pp. 59-71.

Batu, A., 2012. Helal (Mahzursuz) Gida Belgelendirmesindeki Sorunlar ve Çözüm Önerileri (The Problems oh Halal Food Certification and Suggestions of Its Solution). Electronic Journal of Food Technologies, 7(2), pp. 60-75.

Batu, A. \& Regenstein, J. M., 2014. Halal Food Certification Challanges and Their Implications for Muslim Societies Worldwide. The International Periodical For The Language, Literature and History of Turkish or Turkic, 9(111), pp. 111-130.

Bin Mohamad, A. B. et al., 2012. Changing in the aspect of nature and name (istihalah): its point of view in the Islamic law. Research journal of Applied Sciences, 7(2), pp. 113-118. 
Bohari, A. M., Hin, C. W. \& Fuad, N., 2013. The Competitiveness of Halal Food Industry in Malaysia: A SWOT - ICT analysis. GEOGRAFIA Online TM Malaysia Journal of Society and Space, 9(1), pp. 1-9. Bonne, K. \& Verbeke, W., 2008. Religious Values Informing Halal Meat Production and the Control and Delivery of Halal Credence Quality. Agriculture and Human Values, Volume 35, pp. 35-47.

CAC, 1997. CAC/GL 24-1997 General Guidlines for use of the term "Halal", s.l.: Codex Alimentarius Comission.

CAC, 2003. CAC/RCP 1-1969 General Principles of Food Hygiene, s.l.: Codex Alimentarius Comission. CEN, 2016. European Committee of Standardization. [Online]

Available at:

https://standards.cen.eu/dyn/www/f?p=204:7:0::::FSP ORG ID:1168898\&cs=162B95DA0E933055921FF059 C54D5ADA0

[Accessed 16 May 2016].

Ceranic, S. \& Božinovic, N., 2009. Possibilities and significance of HAS implementation (Halal Assurance System) in existing quality systemin food industry. Biotechnology in Animal Husbandry, 25(3-4), pp. 261-266. Dağ, H. \& Erbasi-Gonc, E., 2013. SMIIC and Halal food standards. Journal ofChemical Metrology, 7(1), pp. 16.

Dahlan, W. et al., 2013. Multi-Approach Management for Halal Security in HACCP-Compliant Seafood Enterprises in Thailand. Middle-East Journal of Scientific Research, 13(4), pp. 464-471.

Dalen, R. v. \& Waarden, F. v., 2012. Creating order in the chaotic world of standards.28th EGOS Colloquium, for workshop 'Multiplicity and Plurality in the World of Standards'.

Deparment of Standards Malaysia, 2004. Halal Food - Production, Preparation, Handling and Storage General Guidlines (FIrst Revision), Putrajaya: Department of Standards Malaysia. Department of Standards of Malaysia, 2009. MS1500(2009)(English): Halal Food - Production, Preparation, Handling and Storage - General Guidlines (Second Revision), Selangor Darul Ehsan: Department of Standards of Malaysia.

Din, R. C. \& Duad, S., 2014. Critical Success Factors of MS1500:2009 Implementation. Procedia-Social and Behavioral Sciences, Volume 121, pp. 96-103.

Duad, S. et al., 2011. Implementation of MS1500:2009: A Gap Analysis.IBIMA Publishing, Volume 2011, pp. $1-11$.

DVS, 2015. Implementation of Inspection Service at Foregin Abattoirs and processing plants for export of meat and products of animal origin to Malaysia. [Online]

Available at: http://www.dvs.gov.my/dvs/resources/auto\%20download\%20images/560b9bca7240c.pdf

[Accessed 29 January 2016].

ESMA, 2015. Form 1: Proposal for a New Field of Technical Activity, Version 01/2015. [Online]

Available at: http://www.standards.co.nz/assets/International-engagement/New-work-item-proposals/201415-

NWIPs/Proposal.pdf

[Accessed 13 December 2015].

Farooqui, M. A. A. \& Kurt, N., 2013. Inspection Procedures in Halal Food Certification. Biannual \&

Multilingual Research Journal for Islamic Social Sciences, 39(28), pp. 17-32.

Farouk, M. M., Puffpaff, K. M. \& Amir, M., 2016. Industrial halal meat production and animal welfare: a review. Meat Science, p. Article in Press.

FDA, 2012. Bad Bug Book (2nd edition). [Online]

Available at: http://www.fda.gov/Food/FoodborneIllnessContaminants/CausesOfIllnessBadBugBook/ [Accessed 5 May 2016].

Fernando, Y., Ng, H. H. \& Yusoff, Y., 2014. Activities, motives and external factors influencing food safety manament systemadoption in Malaysia. Food Control, Volume 41, pp. 69-75.

GFSI, 2015. The Global Food Safety Initiative. [Online]

Available at: http://www.mygfsi.com/about-us/about-gfsi.html

[Accessed 19 November 2015].

GIMDES, 2015. Gıda ve İhtiyaç Maddeleri Denetleme ve Sertifikalandırma Araştırmaları Derneği. [Online]

Available at: http://www.gimdes.org

[Accessed 27 October 2015].

Golnaz, R., Zainalabidin, M. \& Mad Nasir, S., 2012. Non-Muslim consumers’ understanding of Halal principles in Malaysia. Journal of Islamic Marketing, 3(1), pp. 35-46.

Golnaz, R., Zainalabidin, M., Mad Nasir, S. \& Eddie Chiew, F. C., 2010. Non-Muslims’ Awareness of Halal Principles and Related Food Products in Malaysia. International Food Research Journal, Volume 17, pp. 667674.

Hakim, L., 2013. The Industrial Future Vision of Halal Model. Farwaniyah, azkahalal.

Halim, M. A. A. \& Ahmad, A. A., 2014. Enforcement on Consumer Protection Laws on Halal Products: Malaysian Experience. Asian Social Science, 10(3), pp. 9-14. 
Halim, M. A. A. \& Salleh, M. M. M., 2012. The Possibility of Uniformity on Halal Standards in Organization of Islamic Countries (OIC) Country. World Applied Sciences Journal, Volume 17, pp. 6-10.

Hanzaee, K. H. \& Ramezani, M. R., 2011. Intention to Halal Products in the World of Markets.

Interdisciplinary Journal of Research in Business, 1(5), pp. 1-7.

Harvey, R., 2010. Certificaiton of Halal Meat in the UK, Cambridge: The University of Cambridge.

Hashimi, D., Saifuddeen, M. \& Salleh, M., 2010. A Background on Halal Industry and Principles. In: International Workshop for Islamic Scholars on Agribiotechnology: Shariah Compliance. Georgetown: Malaysia Biotechnology Information Center (MABIC), The International Service for the Acuisition of Argibiotech Applications (ISAAA), pp. 12-20.

HDC, 2015. Halal Industry Development Corporation. [Online]

Available at: http://www.hdcglobal.com/publisher/bi halal standards

[Accessed 18 October 2015].

H-Media, 2011. The International Halal SME Report \& Directory 2011/12. [Online]

Available at: http://halalsme.com/wp-content/uploads/2013/04/IHSMERD2012-ebook.pdf

[Accessed 18 October 2015].

Iberahim, H., Kamaruddin, R. \& Shabudin, A., 2012. Halal Development System: The Institutional Framework, Issues and Challanges for Halal Logistics. Business, Engineering and Industrial Applications (ISBEIA), IEEE Symposium, pp. 760-765.

IHIA, 2015. International Halal Integrity Alliance. [Online]

Available at: http://www.hialliance.org

[Accessed 9 May 2015].

International Trade Centre, 2015. From Niche to Mainstream Halal Goes Global, Geneva: International Trade Centre (ITC).

Ireland, J. \& Rajabsadeh, S. A., 2011. UAE consumer concerns about halal products. Journal of Islamic Marketing, 2(3), pp. 274-183.

Is mail, R., 2011. Food and Consumer Protection: A Study on Food Legilation of Selected Countries, Singapore: Asian Law Institute.

ISO, 2015. International Organization for Standardization. [Online]

Available at: http://www.iso.org/

[Accessed 9 May 2015].

Jahangir, M. et al., 2016. Halal status of ingredients after physiochemical alteration (Istihalah). Trends in Food Science \& Technology, Volume 47, pp. 78-81.

JAKIM, 2012. Guidelines For Halal Assurance Management System, Selangor: Halal Hub Devision. JAKIM, 2016. About JAKIM. [Online]

Available at: http://m.islam.gov.my/en/about-jakim

[Accessed 15 May 2016].

Jamaludin, M. A. et al., 2011. Istihalah: Analysis on the utilization of gelatin in Food Products.2nd

International Conference on Humanities, Historical and Social Sciences, Volume 17, pp. 174-177.

Kadir, M. R. A., Zaino, Z., Duad, S. \& Sapuan, N. M., 2015. Incorporating the Cost Management System in Halal Standard MS 1500:2009 Halal Food in Malaysia. International Research Journal of Education and Innovation, 1(4), pp. 1-12.

Kamali, M. H., 2008. Sharia'ah Law: An Introduction. Oxford: Onewordl Publications.

Kamaruddin, R. et al., n.d. Halal Global Analytic Hierarchy Parameters: A Conceptual Assessment. [Online] Available at: http://www.isahp.org/uploads/57.pdf

[Accessed 29 October 2015].

Kamaruddin, R., Iberahim, H. \& Shabudin, A., 2012. Halal Compliance Critical Control Point (HCCCP) Analys is of Processed Food. IEEE Business, Engineering \& Industrial Applications Colloquium(BEIAC), pp. 384-387.

Kamaruddin, R., Iberahim, H. \& Shabudin, A., 2012. Willingness to Pay for Halal Logistics: The lifestyle Choice. Procedia - Social and Behavioural Sciences, Volume 50, pp. 722-729.

Kassim, N., Hashim, P., Hashim, D. M. \& Jol, H., 2014. New approach of Samak Clay Usage for Halal Industry Requirement. Procedia - Social and Behavioral Sciences, Volume 121, pp. 186-192.

Kayadibi, S., 2014. A Way Forward to European Standard on Halal Food. Journal of Asian Development Studies, June, 3(2), pp. 105-116.

Khalek, A. A., 2014. Young Consumers' Attitude Towards Halal Food Outlets and JAKIM’s Halal Certification in Malaysia. Procedia - Social and Behavioral Sciences, Volume 121, p. 26 - 34.

Kohilavani, et al., 2012. A Decision Tree Based Approach for the Identification of Halal Critical Control Point for Slaughter According to Islamic Dietary Law. Internet Journal of Food Safety, Volume 14, pp. 48-53. Kohilavani, et al., 2013. Embedding Islamic Dietary requirements into HACCP approach. Food Control, Volume 34, pp. 607-612. 
Lateef, H. K., n.d. Harmonization of Halal Food Standards. [Online]

Available at:

http://www.halalpakistan.com/images/presentations/Hamid\%20K.\%20Lateef,\%20Chairman\%20PSQCA,\%20St anding\%20Committee\%20for\%20Halal\%20Food\%20Standards.pdf

[Accessed 4 May 2016].

Latif, a. I. et al., 2014. A Comparative Analysis of Global Halal Certification Requirements. Journal of Food

Products Marketing, Volume 20, pp. 85-101.

LPPOM MUI, 2008. General Guidelines of Halal Assurance System, Jakarta: LPPOM MUI.

LPPOM MUI, 2016. LPPOM MUI - About Us. [Online]

Available at: http://e-lppommui.org/other/about us.php

[Accessed 15 May 2016].

Majid, M. A. A., Abidin, I. H. Z., Majid, H. A. M. A. \& Chik, C. T., 2015. Issues of Halal Food Implementation in Malaysia. Journal of Applied Environmental and Biological Sciences, 5(6S), pp. 50-56.

Malaysia government, 2011. Halal Malaysia Official Portal. [Online]

Available at: http://www.halal.gov.my/v4/index.php/en/garis-panduan-mobile/akta-perintah-perdagangan

[Accessed 9 May 2015].

Manzouri, M., Rahman, M. N. A., Saibani, N. \& Zain, C. R. M., 2013. Lean Supply Chain Practices in the Halal food. International Journal ofLean Six Sigma, 4(4), pp. 389-408.

Marzuki, S. Z. S., Ballantine, C. M. H. \& Ballantine, P. W., 2012. Restaurant managers' perspective on halal certification. Journal of Islamic Marketing, 3(1), pp. 47-58.

MITI, 2006. Ministry of International Trade and Industry. [Online]

Available at: http://www.miti.gov.my/cms/content.jsp?id=com.tms.cms.section.Section 8ab58e8f-7f00001072f772f7-dbf00272

[Accessed 29 March 2015].

Mohamed, N. \& Backhouse, C., 2014. A Framework of the Development of Halal Food Products in Malaysia. Proceedings of the 2014 International Conference on Industrial Engineering and Operations Management, pp. 693-702.

Mohtar, N. M., Amirnordin, N. A. \& Haron, H., 2014. Ayamas Food Corporation Sdn. Bhd: A Study on the Factors of Consumer Behaviour Towards Halal Product Selection. Procedia - Social and Behavioral Science, Volume 121, pp. 166-185.

Muhammad, N. M. N., Isa, F. M. \& Kifli, B. C., 2009. Positioning Malaysia as Halal-Hub: Integration Role of Supply Chain Strategy and Halal Assurance System. Asian Social Science, 5(7), pp. 44-52.

Nakyinsige, K. et al., 2012. Halal Meat: A Niche Product in the Food Market. 2nd International Conference on Economics, Trade and Development, Volume 36, pp. 167-173.

Nasaruddin, R. R., Faud, F., Jaswir, I. \& Hamid, H. A., 2011. The Importance of a Standardized Islamic Manufactyring (IMP) for Food and Pharmaceutical Productions. 2nd International Conference on Professional Ethics and Education in Engineering, pp. 401-408.

Ngah, A. H., Zainuddin, Y. \& Thurasamy, R., 2014. Adoption of Halal Supply Chain amond Malaysian Halal Manufacturers: An Explanatory Study. Procedia - Social and Behaviour Science, Volume 129, pp. 388-395. Noordin, N., Noor, N. L. M., Hashim, M. \& Samicho, Z., 2009. Value chain of halal certification system: A case of the Malaysia halal industry. European and Mediterranean Conference on Information Systems, pp. 1-14. OIC, 2016. Organisation of Islamic Cooperation -Subsidiary. [Online]

Available at: http://www.oic-oci.org/oicv3/page/?p id=64\&p ref=33\&lan=en\#FIQH

[Accessed 15 May 2016].

Omar, E. N., Jaafar, H. S. \& Osman, M. R., 2013. Halalan Toyyiban Supply Chain of the Food Industry. Journal of Emerging Economics and Islamic Research, 1(3), pp. 1-12.

Omar, E. N., Jaafar, H. S., Osman, M. R. \& Nasruddin, F., 2013. Halalan Toyyiban supply chain the new insights in sustainable supply chain management. Paper presented at the ICLT.

Omar, S. N., Omar, S. R. \& Karim, S. A., 2014. Perceived Importance on Malaysian Halal and Authentic Heritage Food (HAHFo): International Muslim Tourists' Purchase Intention Behavious. Proceedings of SOCIOINT14 - International Conference on Social Sciences and Humanities, pp. 954-960.

Pew Research Center, 2011. The Future of the Global Muslim Population Projections for 2010-2030, Washington: Pew Research Center's Forum on Religion \& Puclic Life.

Pointing, J., 2014. Strict Liability Food Law and Halal Slaughter. The Journal of Criminal Law, Volume 78, pp. 387-391.

Poniman, D., Pruchase, S. \& Sneddon, J., 2015. Traceability Systems in the Western Australia Halal Food Supply Chain. Asia Pacific Journal of Marketing, 27(2), pp. 324-348.

PSQCA, 2013. Pakistan Standards and Quality Control Authority, Ministry of Science and Technology. [Online] 
Available at: http://psqca.com.pk/test2/index.html

[Accessed 4 May 2016].

Rahman, M. M., Khatun, M. M., Rahman, M. H. \& Ansary, N. P., 2014. Food safety issues in Islam. Health, Safety and Environment, 2(6), pp. 132-145.

Rahman, R. A. et al., 2014. Exploring the OIC Food Manufacturer Intention Towards Adopting Malaysian Halal Certification. American Journal of Food Technology, 9(5), pp. 266-274.

Rahman, R. A. et al., 2013. Malaysia as Global Halal Hub: OIC Food Manufacturers' Perspective.. Journal of International Food \& Agribusiness Marketing, Volume 25, pp. 154-166.

Rahman, S. A., Rahman, A. A. \& Aliaziz, M. H., 2013. Genetically Modified Organisms (GMOs) and the Issue of Safety and Halal in Malaysia. Australian Journal of Basic and Applied Sciences, 7(12), pp. 238-244.

Ratanamaneichat, C. \& Rakkarn, S., 2013. Quality Assurance Development of Halal Food Products for export to Indonesia. Procedia - Social and Behavioras Sciences, Volume 88, pp. 134-141.

Riaz, M. N. \& Chaundry, M. M., 2004. Halal Food Production. Boca Raton, London, New York, Washington, D. C.: CRC Press LLC.

Ruzevicius, J., 2012. Products Quality Religious-Ethical Requirements and Certification. Economics and Management, 17(2), pp. 761-767.

Said, M., Hassan, F., Musa, R. \& Rahman, N., 2014. Assessing Consumers’ Perception, Knowledge and Religiosity on Malaysia’s Halal Food Products. Procedia - Social and Behavioral Sciences, Volume 130, pp. 120-128.

Said, M. M. \& Elangkovan, K., 2013. Halal Label and the Ethics of Business: An Analytical View From Producers. Australian Journal of Basic and Applied Science, 7(6), pp. 613-621.

Saifuddeen, S. M. \& Salleh, S. M., 2013. Being healthy by eating permitted and quality food. [Online] Available at: http://www.ikim.gov.my/index.php/en/the-star/7057-being-healthy-by-eating-permitted-andquality-food

[Accessed 26 November 2015].

Salama, S., 2015. Gulf News. [Online]

Available at: http://gulfnews.com/news/uae/government/uae-to-ramp-up-battle-against-food-safety-offenders1.1445963

[Accessed 9 May 2015].

Samori, Z., Ishak, A. H. \& Kassan, N. H., 2014. Understanding the Development of Halal Food Standard Suggestion for Future Research. International Journal of Social Science and Humanity, 4(6), pp. 482-482.

Samori, Z. \& Sabtu, N., 2014. Developing Halal Standard for Malaysian Hotel Industry: An Exporatory Study. Procedia - Social and Behavioral Sciences, Volume 121, pp. 144-157.

Samsi, S. Z. M., Ibrahim, O. \& Tasnim, R., 2012. Review on Knowledge Management as a Tool for Effective Traceability System in Halal Food Industry Supply Chain. Journal of Research and Innovation in Information Systems, Volume 78-85.

Shafii, Z. \& Khadijah, W. M. N. W. S., 2012. Halal Traceability Framework for Halal Food Production. World Applied Sciences Journal, Volume 17, pp. 1-5.

Shallah, M. F. M. \& Hussin, R., 2013. Halal assurance systemrequirements and documentation in cosmetics industry. Proceedings of international conference on Halal issueas and policies, Makasar.

Shariff, S. M. \& Abd Lah, N. A., 2014. Halal Certification on Chocolate Products: A Case Study. Procedia Social and Behavioral Sciences, Volume 121, pp. 104-112.

Sirajuddin, M. D. M. et al., 2013. Introducing Halalan Tayyiban Concept in Global Industry Practices: An Innovative Attempt. International Proceedings ofEconomics Development and Research, Volume 66. Spiegel, v. d. M. et al., 2012. Halal assurance in food supply chains: Verification of halal certificates usind audits and laboratory analysis. Trends in Food Science \& Technology, Volume 12, pp. 109-119.

Tahir, I. R. \& Abdul, M., 2013. The Role of Religious Orientation in the Business Performance of Women Owned Firms: A Preliminary Study in Malaysia Halal Food Industry. A Multidisciplinary Journal of Global Macro Trends, 2(3), pp. 40-45.

Tahir, I. R., Junaidu, A. \& Bashir, M., 2015. The Role of Quality Assurance in Pahang Halal Food Industry in Malaysia. Journal of Business Administration and Management Science Research, 4(3), pp. 60-68.

Talib, H. H. A., Ali, K. A. M. \& Jamaludin, K. R., 2008. Quality Assurance in Halal Food Manufacturing in Malaysia: A Preliminary Study. Proceedings on International Conference on Mechanical \& Mandufacturing Engineering,pp. 1-5.

Talib, M. S. A. \& Hamid, A. B. A., 2014. Halal Logistics in Malaysia: a SWOT analysis. Journal of Islamic Marketing, 5(3), pp. 322-343.

Talib, M. S. A., Hamid, A. B. A. \& Zulfakar, M. H., 2015. Halal Supply Chain Critical Success Factors: a Literature Review. Journal of Islamic Marketing, 6(1), pp. 44-71.

Talib, Z., Zailani, S. \& Zainuddin, Y., 2010. Conceptualizations on the Dimensions for Hala Orientation for Food Manufacturers: A Study in the Context of Malaysia. Pakistan Journal of Social Sciences, 7(2), pp. 56-61. 
Tan, M. I. I., Razali, R. N. \& Desa, M. I., 2012. Factors Influencing ICT Adoption in Halal Transportations: A Case Study of Malaysian Halal Logistics Service Providers. International Journal ofComputer Science Issues, 9(1), pp. 62-71.

Tarighat-Esfanjani, A. \& Namazi, N., 2014. Nutritional Concepts and Frequency of Foodstuffs Mentioned in the Holy Quran. Journal of Religion and Health, 04(April).

Tarmizi, H. A., Kamarulzaman, N. H., Latiff, I. A. \& Rahman, A. A., 2014. Factors Behind Third-Party Logistics Providers Readiness Towards Halal Logistics. International Journal ofSupply Chain Management, 3(2), pp. 53-62.

Tarzimi, H. A., Kamarulzaman, N. H., Latiff, I. A. \& Rahman, A. A., 2014. Factors Influencing readiness towards halal logistics among foodbased logistics players in Malaysia. UMK Procedia, Volume 1, pp. 42-49. The Halal Journal, 2008. Fiqh-based Approach to Harmonisation of Halal Standards. The Halal Journal, Volume May/June, p. 112.

Thomas Reuters, 2013. State of the Global Islamic Economy. [Online]

Available at: http://www.assaif.org/

[Accessed 14 December 2015].

Tieman, M., 2011. The Application of Halal in Supply Chain Management: in-dept Interviews. Journal of Islamic Marketing, 2(2), pp. 186-195.

Tieman, M., 2013. Establishind the Principles in Halal Logistics. Journal of Emerging Economics and Islamic Research, 1(1), pp. 1-13.

Tieman, M. \& Ghazali, M. C., 2014. Halal Control Activities and Assurance Activities in Halal Food Logistics. Procedia - Social and Behavioral Sciences, Volume 121, pp. 44-57.

Tieman, M., Ghazali, M. C. \& Vorst, J. G. A. J. v. d., 2013. Consumer Perception on Halal Meat Logistics. British Food Journal, 115(8), pp. 1112-1129.

Tieman, M. \& Hassan, F. H., 2015. Convergence of food systems:Kosher, Christian and Halal. British Food Journal, 117(9), pp. 2313-2327.

Tieman, M., Vorst, J. G. A. J. v. d. \& Ghazali, M. C., 2012. Principles in Halal Supply Chain Management. Journal of Islamic Marketing, 3(3), pp. 217-243.

USDA, 2011. Malaysia Food and Agricultural Import Regulations and Standards - Narrative. [Online] Available at:

http://gain.fas.usda.gov/Recent\%20GAIN\%20Publications/Food\%20and\%20Agricultural\%20Import\%20Regula tions\%20and\%20Standards\%20-\%20Narrative Kuala\%20Lumpur Malaysia 12-28-2011.pdf

WHF, 2009. World Halal Forum. [Online]

Available at: http://www.worldhalalforum.org/download/WHF09Report(compressed).pdf

[Accessed 18 October 2015].

WHF, 2013. World Halal Forum. [Online]

Available at: http://www.worldhalalforum.org/download/WHF2013 post event report.pdf

[Accessed 9 May 2013].

WHO, 2007. WHO Initiative to Estimate the Global Burden of Foodborne Diseases. [Online]

Available at: http://www.who.int/foodsafety/publications/foodborne disease/FERG Nov07.pdf

[Accessed 9 May 2015].

WTO, 2012. Specific trade concerns - G/TBT/M/56 paras. 195-199. [Online]

Available at: http://tbtims.wto.org/web/pages/edition/stc/SpecificTradeConcern.aspx?ID=250573

[Accessed 27 November 2015].

WTO, 2015. SPS Information Management System. [Online]

Available at: http://spsims.wto.org/web/pages/search/stc/Search.aspx

[Accessed 27 November 2015].

WTO, 2015. TBT Information Management System. [Online]

Available at: http://tbtims.wto.org/web/pages/search/stc/Search.aspx

[Accessed 27 November 2015].

Yunus, A. B. M., Chik, W. M. Y. B. W. \& Mohamad, M. B., 2010. The Concept of Halalan Tayyiba and Its Application in Products Marketing: A Case Study at Sabasun HyperRuncit Kuala Terengganu, Malaysia. International Journal of Business and Social Science, 1(3), pp. 239-248.

Zailani, S. et al., 2010. Halal Traceability and Halal Tracking Systems in Strenghtening Halal Food Supply Chain for Food Industry in Malaysia (Review). Journal of Food Technology, 8(3), pp. 74-81.

Zailani, S. H. M. et al., 2010. Recommendations to strengten Halal Food Supply Chain for Food Industry in Malaysia. Journal of Argribusiness Marketing, pp. 91-105.

Zakaria, Z., 2008. Tapping Into the World Halal Market: Some Discussions on Malaysian Law and Standards. Shariah Journal, Volume 16, pp. 603-606.

Zikrullah, A. L., 2014. The teory of Shariah Rulings in Halal Meat and Poultry Production. International Journal of Management Science, 3(5), pp. 351-369. 
1004 Zulfakar, M. H., Anuar, M. M. \& Talib, M. S. A., 2014. Conceptual Framework on Halal Food Supply Chain 1005 Integrity Enhancement. Proceadia-Social and Behavioural Science, Volume 121, pp. 58-67. 